\title{
Museopedagogiikka ja aikuiskasvatus
}

\section{LEENA TORNBERG}

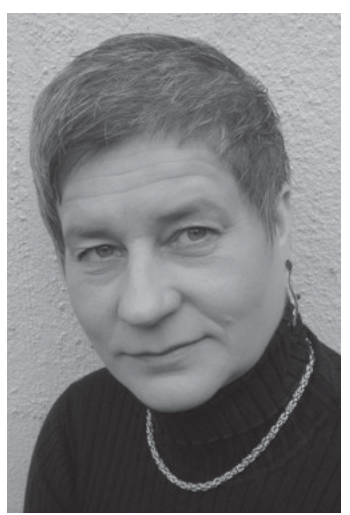

Pedagogiikka ei voi olla museon erillinen yksittäinen osio, vaan se on museon läpikulkeva toiminta tai ajatus. Museoiden opetuksellisessa toiminnassa on siirrytty elinikäisen oppimisen periaatteelle. Yhteinen tekijä kaikissa on, että toiminnalla on tavoite - kasvatuksellinen, opetuksellinen tai jopa vain elämyksellinen - johon pedagogiikan eri keinoin pyritään. uhuttaessa museopedagogiikasta suomen kielessä se yhdistetään usein museossa lapsiin tai museoiden ja perusasteen koulujen yhteistyöhön. Jouko Heinonen (2002) ihmettelee Museo-lehdessä:

"Vaikka museot soveltuvat erityisesti aikuiskoulutukseen, puuhaavat suomalaiset museot kuitenkin erityisesti koululaisten kanssa. Miksi?"

Aluksi toiminta onkin ollut lapsiin suuntautunutta, koska heissä on tulevaisuuden käyttäjät. Mitä enemmän museopedagogiikkaan on tullut ammattilaisia, sitä enemmän on huomattu, että sekä museoissa että arkistoissa tarvitaan myös aikuisille suunnattua pedagogista toimintaa.

Museopedagogiikan saralla on tapahtunut paljon kansainvälisesti 1960-luvulta lähtien. Suomessa suurin kehitys on tapahtunut 1990-luvulla sekä vuosituhannen alussa. Elokuussa 2008 Kansallismuseolla pidetyssä seminaarissa oli luennoitsijana Ruotsin ensimmäinen arkistopedagogi Karin Sjöberg. Hänen kuvailussaan arkistopedagogiikan tarkoituksesta ja arkistopedagogiikasta perustelut olivat samat, joiden pohjalle museopedagogiikka ja museopedagogien tarpeellisuus museoissa todettiin noin 30 vuotta sitten.

Pohjoismaissa on alettu pohtia pedagogiikan yhteneväisyyksiä arkisto-, kirjasto- ja museoympäristössä. Museot ja arkistot sisältävät kaikille ihmisille kuuluvaa yhteistä kulttuuriperintöä, mutta sitä osaa käyttää hyväkseen vain pieni osa väestöstä. Materiaalia jää hyödyntämättä sen vuoksi, että materiaalin sisällöistä, jopa olemassaolosta ja mahdollisuudesta käyttää instituutioiden palveluja, ei olla tietoisia. Kyseessä olevissa instituutioissa on käännytty pedagogiikan puoleen, jotta opittaisiin, miten näitä instituutioita voidaan käyttää monipuolisesti.

Kirjallisuudessa museopedagogiikan yhteydessä puhutaan kommunikaatiosta, viestinnästä, yleisöpalvelusta, jopa markkinoinnista (HooperGreenhill 1995; Hein 1998; Kallio 2004; MalmisaloLensu \& Mäkinen 2007, Kaitavuori 2007). Nykyään on mahdotonta erottaa museossa toisistaan museopedagogiikkaa, museon viestintää ja yleisötyön eri muotoja. Uusimmassa kirjallisuudessa oppimisen näkökulma liitetään läheisesti myös näyttelysuunnitteluun (Houtgaard \& Vitali 2008). Pedagogiikka ei voi olla museon erillinen yksittäinen osio, vaan se on museon läpikulkeva toiminta tai ajatus. Etenkin aikuiskasvatuksen osalta museopedagogiikka on samalla myös yleisötyötä.

Museokasvatuksella on useita eri muotoja tämän päivän museoissa lähtien alle kouluikäisten ohjelmista ikääntyneiden muisteluryhmien palve- 
luun. Museoiden opetukselliset toiminnat eivät ole suunnattuja enää vain lapsille ja nuorille, vaan museoissa on siirrytty elinikäisen oppimisen periaatteelle. Yhteinen tekijä kaikissa on, että toiminnalla on tavoite - kasvatuksellinen, opetuksellinen tai jopa vain elämyksellinen - johon pedagogiikan eri keinoin pyritään. Museopedagogiikkaa ehkä parempi sana nykykielessä onkin museokasvatus ${ }^{1}$. Tässä artikkelissa käytän termiä museokasvatus synonyyminä museopedagogiikalle, sikäli kun sitä ei erikseen toisella tavalla määritellä.

\section{Museon opetuksellisuuden pohja}

Yleisin tapa määritellä museo löytyy UNESCOn alaisen kansainvälisen museoneuvoston (International Council of Museums, ICOM) Museotyön eettisistä säännöksistä: ”Museo on voittoa tuottamaton pysyvä instituutio, joka toimii yhteiskunnan ja sen kehityksen hyväksi; on avoinna yleisölle; hankkii, säilyttää, tutkii, julkaisee ja esittelee - tutkimusta, kasvatusta ja mielihyvää varten - aineellista ja aineetonta todistusaineistoa ihmisistä ja heidän ympäristöstään.” ICOM Statues, Article 2:definitions (suomennos Suomen ICOM komitea, 2008)

Jouko Heinonen ja Markku Lahti (2001) tarkentavat museon kokoelmien kartuttamisen, dokumentoinnin ja säilyttämisen lisäksi museon perustoiminnoiksi tutkimuksen, näyttelytoiminnan, opetuksen ja kasvatuksen, neuvonnan, julkaisu- ja muu kustannustoiminna n, tiedotus- ja suhdetoiminnan sekä markkinoinnin. Teoksessa korostetaan, että museo on ensisijaisesti tutkimuslaitos ja museo on tallentava instituutio, jota voidaan verrata toiminnaltaan arkistoihin ja tieteellisiin kirjastoihin. Museon opetus- ja palvelutoiminnalla (näyttelyt, julkaisut, esitelmät) nähdään olevan rooli, jolla tutkimuksessa hankittua tietoa välitetään suurelle yleisölle, asianharrastajille ja yksittäisille tutkijoille. Museolaitoksen tehtäväkenttä ja vastuualue on siten varsin laaja.

Heinonen (2001) viittaa museon kuitenkin olevan muuttumassa passiivisesta kerääjästä ja kapea-alaisesta tutkimuslaitoksesta aktiiviseksi osallistujaksi, joka on valmis kohtaamaan nykypäivän haasteita kaikilla luonnon ja ihmisen suhteiden ja olemassaolon tasoilla. Hänen mukaansa museo tulee nähdä enemmän mediana ja resurssina, välineenä ja voimavarana sekä paikkana, joka osallistuu ajan sosiaaliseen keskusteluun. Museon voidaan nähdä opettavan ihmisiä vastuunalaiseen toimintaan ja ajatteluun.

Museo 2000 -komiteamietinnössä (1999) kuvataan myös museon muuttunutta tilannetta:

"Suomalaiset museot ovat viimeisen parinkymmenen vuoden aikana muuttuneet esine- ja kokoelmakeskeisistä laitoksista laaja-alaisiksi kulttuurihistorian, taiteen ja luonnon ilmiöitä sekä ympäristöä säilyttäviksi, tutkiviksi ja esitteleviksi instituutioiksi.”

Komiteamietinnössä museo rinnastetaan tietoa jakavan toimintansa puolesta esimerkiksi kirjastoon. Heinonen (2001) lisää, että museo voidaan nähdä yhteiskunnan tunteena kuten teatteri ja orkesteri. Hänen mukaansa museo toimii myös yhteiskunnan omanatuntona.

Museon perusta on esineissä. Niiden historia ja nykyaika kiteytyvät kokoelmiin. Kokoelmat ovat museotoiminnan kivijalka ja ne ovat karttuneet yleensä vuosikymmenien tai jopa vuosisatojen ajan. Eri aikoina kokoelmien painotusarvot ovat vaihdelleet. Museot voidaan jakaa pääasiallisesti kolmeen eri ryhmään niiden kokoelmien mukaan: kulttuurihistorialliset museot, joita suurin osa Suomen museoista on, taidemuseot, joiden vastuualueena ovat taideteokset, ja luonnontieteelliset museot, jotka huolehtivat luonnontieteellisten näytteiden kokoelmista. Heinonen lisää edellä mainittuun luetteloon termin tiedemuseot (science museum), mitä nimitystä käytetään erityisesti anglosaksisessa maailmassa tieteen ja tekniikan museoista. Suomessa tiedemuseot lasketaan kuuluvaksi kulttuurihistoriallisten museoiden alaryhmäksi. Erikoismuseoksi voidaan nimittää kulttuurihistoriallista museota, joka pyrkii erikoistumaan johonkin ajanjaksoon, tiettyyn maantieteelliseen alueeseen tai jollekin alalle. Esimerkkinä voidaan maininta tiemuseo, urheilumuseo, myllymuseo tai taiteilijoiden tai merkkihenkilöiden kotimuseot.

Museoviraston vuoden 2005 tilaston mukaan Suomessa on yli 1000 museota, joista 328 museota on museoammatillisesti hoidettuja, tarkoittaen, että museo toimii ympärivuotisesti ja kuuluu opetusministeriön valtionavun piiriin. Museoita on siten jokaisen välittömässä läheisyydessä hyödynnettäväksi.

Jouko Heinonen korostaa, että vaikka museot keräävätkin ensi sijassa esineitä ja näytteitä, niihin liittyy yleensä myös täydentävää kirjallista ja kuvallista aineistoa, esimerkiksi tietoa kohteen synnystä ja käytöstä. Tällainen tieto on yhtä arvokasta museolle kuin itse esinekin. (Hein 1998, 
Hooper-Greenhill 1994, 1995, Gesché-Koning 2007, Heinonen 2001, Kallio 2004)

\section{Museopedagogiikka - museo- kasvatus - museum education}

Museoiden kasvatustehtävä määritellään ICOM:in Museotyön eettisissä säännöissä erillisessä artiklassa:

"Museoilla on tärkeä velvollisuus kehittää kasvatuksellista rooliaan ja houkutella laajempia yleisöjä siitä yhteisöstä tai ryhmästä ja siltä seudulta, jota ne palvelevat. Vuorovaikutus yhteisön kanssa ja sen kulttuuriperinnön vaaliminen muodostavat oleellisen osan museon kasvatuksellisesta tehtävästä.”

Määritelmä on edelleen hyvin avoin, joten jokainen museo soveltaa kasvatustehtäväänsä omien painotusten mukaisesti. Tästä johtuu vaikeus löytää selkeää yksiselitteistä määritelmää, mitä museopedagogiikalla tai museokasvatuksella tarkoitetaan. Kun puhutaan museokasvatuksesta ja aikuiskasvatuksesta, enemmän puhutaan museon yleisestä tavasta kohdata yleisönsä. Kaija Kaitavuori (2007) huomauttaa, että englanninkielisessä kontekstissa museokävijöitä nimitetään yleisesti oppijoiksi. Suomessa termi sidotaan liian usein vain museopedagogiikkaan ja museopedagogeihin. Museoiden kasvatuksellinen vastuu koskee kaikkia ikäluokkia ja kaikkia museokävijöitä.

Museum education -termi on käännetty suomeksi pitkään sanalla museopedagogiikka. Tähän ovat vaikuttaneet kielet, joista materiaalia Suomeen on tullut (saksaksi Museumspädagogik, ruotsiksi museipedagogik). ${ }^{2}$ Englanninkielinen verbi educate kattaa suomen kielessä merkitykset 'opettaa' ja 'kasvattaa', kuten Heinonen ja Lahti toteavat, mutta se kattaa myös merkityksen 'sivistää'. Tämän vuoksi Suomessakin käytetään nykyään rinnakkaisena terminä jo yleisesti museokasvatusta (vrt. teknologiakasvatus, kulttuurikasvatus, teatterikasvatus). Jos halutaan korostaa museon toimintamuotona juuri opetusta, pedagogisia menetelmiä, voidaan käyttää myös termiä museo-opetus tai museopedagogiikka. Museon yksi tärkeimmistä tavoitteista on, että ne ovat yleissivistäviä laitoksia - tiedon, taidon ja kokemuksen välittäjiä - olipa kävijä minkä ikäinen tahansa. (HeinonenLahti 2001, Kaitavuori 2007, Malmisalo-Lensu \& Mäkinen 2007)

Kun puhutaan kasvatuksesta, joudutaan käsit- telemään myös termiä oppiminen. Mitä siten museossa tulisi oppia? Maijaliisa Rauste-von Wrightin ja Johan von Wrightin määritelmä oppimiselle antaa pohjaa:

Ihmisen ns. kognitiiviset toiminnot kuten havaitseminen, muistaminen ja ajatteleminen nivoutuvat toisiinsa saumattomasti. Ihmiselle ominainen informaation prosessointi (sen vastaanotto, muokkaus ja tulkinta) on jatkuva, kokonaisvaltainen prosessi. Se (voi) aiheuttaa muutoksia tiedoissamme, käsityksissämme, taidoissamme, tunteissamme ym. Kun tämä muutos kestää kauemmin kuin hetken, kutsumme sitä oppimiseksi.

Vastaavasti Sirkka Hirsjärven ja Jouko Huttusen mukaan oppiminen on tiedon ja kokemusten kartuttamista siten, että ihmisen tietoisuudessa ja toiminnassa tapahtuu muutos. Nämä määritelmät on otettu pohjaksi tässä artikkelissa määriteltäessä museokasvatusta. Mikäli museossa käynti aiheuttaa tai on aiheuttanut muutoksen tiedoissa, taidoissa, käsityksissä tai tunteissa ja se kestää kauemmin kuin vain näyttelyssä oloajan, katsotaan oppimista museossa tapahtuneeksi.

Rauste-von Wrightin ja Wrightin näkemyksen mukaan kasvatus, koulutus ja opetus kuuluvat samaan käsiteperheeseen, missä kaikissa on kysymys kasvavaan yksilöön vaikuttamisesta. Kasvatusta pidetään laajimpana käsitteenä, koulutus on suppeampi ja opetus on keino molempien toteuttamisessa. Kasvatus voidaan nähdä kokonaisvaltaisimpana toimintana, kun taas koulutuksen tavoite voi olla rajatumpi. Kasvatus on pitkäaikaista, jopa koko eliniän kestävää. Kasvatus voi olla jatkuvaa vaikuttamista ihmiseen. Se on kokonaisvaltaista ja monipuolisesti ihmiseen vaikuttavaa, minkä taustalla on sivistyksen ideaali ja lopullisesti persoonallisuuden syntyminen. Museokasvatus voidaan laajimmillaan nähdä pedagogiikkatermin väljimpänä määrittelynä. (Heinonen \& Lahti 2001, Hirsjärvi \& Huttunen 1997, Malmisalo-Lensu \& Mäkinen 2007, Rauste-von Wright \& Wright 1995)

\section{Museot informaaleina oppimisympäristöinä}

Museoiden aikuiskasvatus kuten opetustoiminta yleensä voidaan katsoa alkaneeksi 1800-luvun puolella, kun opastustoiminta museoissa aloitet- 
tiin. Museoissa huomattiin, että yleisö, joka saapui katsomaan valistusajan innoittamina esille asetettuja esineitä tai taideteoksia, eivät ymmärtäneet välttämättä niiden merkitystä. Museot alettiin nähdä koulun ohella kaikkien mahdollisuutena sivistyä. Malmisalo-Lensu ja Mäkinen puhuvat koko kansalle demokraattisesti kuuluvasta oppimisympäristöstä. Esimerkkinä historiasta he kertovat Seurasaaren ulkomuseon, jossa A.O. Heikel kutsui viime vuosisadan alkupuolella sanomalehdessä kaupunkilaisia kirkkokahveille saareen.

Suomessa ensimmäisenä opastustoiminnan aloitti Ateneumin taidemuseo. Vuonna 1902 Kaunotieteellinen Yhdistys kokosi ryhmän innokkaita oppaita ja he ryhtyivät järjestämään opastettuja kiertokäyntejä Ateneumiin "selittäen esitellä taidekokoelmia työtätekevälle luokalle”. Sen aikaiset oppimissuunnat edustivat pääasiallisesti behavioristista tiedon siirtoa asiantuntijalta ei-asiantuntijayleisölle.

Toisen maailmansodan jälkeisenä aikana keskeytyi museoiden aloittama opetuksellinen ajattelu. Sodan jälkeen keskityttiin kokoelmatyöhön ja sen kehittämiseen. 1960-luvulla opetuksellisuus museoissa nousi kansainvälisellä foorumilla jälleen ajankohtaiseksi. ICOM:iin (Internationa Council of Museums) perustettiin 1950-luvulla alajärjestö CECA (Committee for Cultural Education and Action), jonka tehtävänä on kehittää ja seurata opetuksellisuutta museoissa. Suomessa 1960-luvun lopulla 12 alan keskeisintä kulttuurijärjestöä mm. Kansanvalistusseura, alkoi vaatia laajempia museoiden aukioloaikoja yleisölle, tiedotuksen parantamista ja oheisohjelman lisäämistä etenkin ”kuvataidenäyttelyihin”. (Kallio 2004, Malmisalo-Lensu \& Mäkinen 2007, Gesché-Koning 2007)

\section{Opastuksen uusia tuulia}

Opastus on ollut ja on edelleen museoiden aikuiskasvatuksessa yksi käytetyimmistä menetelmistä. Opastustekniikat, opastusmenetelmät ja opaskoulutus ovat kuitenkin muuttuneet viimeisten vuosikymmenten aikana huomattavasti, joka tuli esille Museopedagogisen yhdistyksen Pedaali ry:n keväällä 2008 järjestämässä seminaarissa Opastuksen uusia tuulia (Pedaali 2008). Seminaarista ilmestyi julkaisu Opastamisen nykypäivää (Kaitavuori ym. 2009)

Nykymuseoissa korostetaan kävijän ja museon kohtaamista, jota opastus yhdessä muodossa edustaa. Kohtaamista ja oppimista voidaan tar- kastella laaja-alaisesti prosesseina tai erilaisina dialogeina keskusteluineen. Taidemuseot ovat olleet edelläkävijöitä opastaessaan sekä aikuisia että lapsia taiteen katsomiseen, kokemiseen ja ymmärtämiseen. Kulttuurihistorialliset ja luonnontieteelliset museot toimivat samalla tavoin riippuen museoiden koon ja valittujen painotusten mukaisesti.

Yksi edelläkävijöistä on ollut yhdysvaltalainen Lisa Roberts, joka on kokeillut ja kehittänyt menetelmiä taidemuseoissa. Menetelmät on sovellettavissa myös muuntyyppisiin museoihin. Roberts nostaa esille tulkinnan, jossa oppijalle ei esitetä vain museon tai yleisen historian tulkintaa asiaan tai ilmiöön, vaan se rakennetaan yhdessä keskustellen eri näkökulmista niiden kesken, keitä tulkintaan osallistuu. Roberts puhuu museon ja kävijöiden neuvottelevasta suhteesta, joka voi parhaimmillaan toimia oppimisprosessina. Tämä edellyttää museolta avointa suhtautumista olemassa olevaan tietoon siten, että tieto ei ole täydellistä tai muuttumatonta. Museoilla on tähän paljon mahdollisuuksia. Museoiden aikuiskävijät tuovat aina mukanaan omat kokemuksensa, muistonsa ja assosiaationsa näyttelyssä esiteltäviin asioihin. Mikäli kävijällä ei ole aikaisempaa suhdetta eikä yhteyttä näyttelyn aiheeseen, museon on annettava ärsyke, johon kävijä voi reagoida. Tässä kohdin ärsykkeen antajana voi toimia pelkkä näyttely, mutta opetuksellisuutta korostettaessa on vaikuttavampi, mikäli ärsykkeen antaja on oikea ihminen, museo-opas tai museolehtori. Malmisalo-Lensu ja Mäkinen ilmaisevat: "Se, miten kävijät reagoivat museon ärsykkeisiin, on osa oppimisprosessia." (Malmisalo-Lensu \& Mäkinen 2007, Roberts 1997)

\section{Museot yleissivistävinä instituutioina - näyttely oppimisympäristönä}

Jokaisessa museossa, jossa on suurelle yleisölle avoin näyttely, tapahtuu kasvatusta. Museonäyttely antaa kävijälle yleissivistävää tietoa kyseessä olevasta näyttelyaiheesta. Kävijät, jotka tulevat museoon, ovat tietoisia tästä vaikutuksesta ja se voi olla syy saapua museoon. Museoiden toiminnoista näyttelyt edustavat parhaiten museossa sattumalta oppimista ja itseoppimista. Kummassakaan oppimistilanteessa ei tarvita opettajaa, opettajan varsinaisessa merkityksessä. Itseoppija voi käyttää kuitenkin hyväkseen oppimistilanteessa jotakin ohjaajaa. Tällainen ohjaaja voi olla lapsi, oppilas, vanhemmat, ystävät, harrastusryhmä tai museovierailulla salivalvoja. (Salmi 1993) 


\section{Museokasvatuksen rinnastaminen teatterikasvatukseen}

Näyttelyt jatkavat museon ja kävijän kohtaamista eettisellä tasolla, jossa kävijöille voidaan selkiinnyttää, miten museo on päätynyt tulkintaansa, olipa kyseessä esineiden kerääminen, kokoelmatietojen keruu, näyttelyn valinnat tai viestinnän painotus. Hirsjärven ja Huttusen käsitystä, jonka mukaan "opetus on oppimisen ohjaamista", voi pohtia museoympäristössä. Tätä voisi kutsua ns. pitkävaikutteiseksi museokasvatustyöksi, jolloin käsitellään kysymyksiä: tuleeko ihmisiä opettaa käymään museossa, voiko tätä taitoa opettaa ja miten. Museoiden parissa asiaa on pohdittu viime vuosikymmenten ajan ja museoiden museopedagogiset yksiköt on osittain luotu vastaamaan tähän haasteeseen. Tavoitteena on saada uusia museokävijöitä.

Ajatusta voi verrata teatterikasvatustyön menetelmiin. Teatterikasvatuksessa yleisölle esitellään teatteriesityksen taustatyötä, miten teatteriesitys syntyy. Kun kävijä tietää esityksen taustatekijöitä, hänen kiinnostuksensa herää toisella tavalla. Teatteriesityksen kokemisen lisäksi hän on tietoinen esityksen taustalla olevista prosesseista esimerkiksi hänen nähtyään, kuinka kohtausta voidaan harjoituksissa tutkailla ja kokeilla eri näkökulmista, mutta vain yksi tulkinta valitaan esitykseen. Samalla tavalla kuin teatterin kohtauksia valmiissa esityksessä pidetään itsestäänselvyytenä, museon näyttelyn esillepanon taustoja voidaan tarkentaa. Mikäli kävijälle esitellään kokoelma-, tallennus- ja näyttelytyön tausta- ja osaprosesseja, itsestäänselvyyksiä voidaan käsitellä kognitiivisella tasolla. (Airaksinen \& Eerola 1997, Hirsjärvi \& Huttunen 1997, Mäkisalo-Lensu \& Mäkinen 2007)

Esimerkkinä voi käyttää museoihin perinteisesti liitettävä ei saa koskea -kokemus. Kävijälle esineen koskemattomuussääntö voi olla vain ulkoinen behavioristinen käsky. Mikäli kävijä saa lisätietoa koskemattomuussäännön museaalisesta taustasta, hyväksyy hän sen helpommin ja ymmärtää sen olevan olennainen osa asiakokonaisuutta. Koskemattomuuteen liittyy adjektiivi aito. Sanan merkitys on museoammattilaisille aivan erilainen kuin kävijälle. Rukinlapa, jonka on nähnyt mummolan aitan vintillä lojumassa, ja rukinlapa, joka on esillä museovitriinissä. Miten esineen aitous on erilaista aitassa ja museossa? Hahmottaako kävijä, mitä museon esineen aitouteen liittyy sellaista, mitä ei ole aitan esineessä? Museopedagogiset ohjelmat pohjautuvat aina kyseessä olevan museon substanssiin, kun ehkä voisivat ottaa enemmän ohjelmaan perehdyttää ihmiset siihen, mikä museo on, mikä sen merkitys on ja kuinka se toimii verraten teatterikasvatuksen menetelmiin.

Marjatta Levanto kirjoittaa oppivan aikakauden -käsitteestä. Se tarkoittaa tässä ajassa muutoksen ja innovaatioiden aikakautta, jossa investoidaan älyyn ja monialaiseen luovuuteen. Tähän liittyvät aikuisoppijoiden kasvavat joukot. Suurissa ikäluokissa löytyy paljon heitä, jotka eivät halua vain kokea museota, vaan myös oppia jotain kokemuksestaan. Oppiminen ei tässä tarkoita vain faktojen oppimista, vaan syvällisempää asioiden välisten yhteyksien ymmärtämistä ja ajatusten linkittämistä. Oppiminen on enemmän kommunikaatiota ja henkistä kasvua. Tarvitaan aktiivista toimintaa, joka opettaa katsomaan tai antaa mahdollisuuden katsoa näyttelyä eri näkökulmista. (Levanto 2004)

\section{Esimerkkejä museopedagogiikan käytännön muodoista}

\section{Opettajien täydennyskoulutus}

Yksittäisten museoiden näkyvin aikuiskasvatusmuoto on ollut opettajille järjestettävät kurssit, uusien näyttelyiden infotilaisuudet sekä VESOpäivät. Opetushallituksen, Museoviraston ja ympäristöministeriön laajat yhteistyöhankkeet Suomen Tammi ja Suomen Tammi+ ovat laajimpia kulttuurikasvatusprojekteja, joissa museot ovat toimineet aikuiskasvatuksen parissa. Lähes kymmenen vuoden ajan museot ovat osallistuneet järjestäjinä alueellisiin ja valtakunnallisiin seminaareihin, joiden osallistujina on ollut sekä opettajia että eri kulttuurintuottajia. Seminaareilla on pyritty lisäämään museoiden ja koulujen ymmärtävää vuorovaikutusta. Koulut ovat voineet tuoda esille opetussuunnitelmien ja käytännön nykykoulun tietämystä museoihin. Vastaavasti museot ovat pystyneet esittelemään omia opetuksellisia ajatuksiaan ja menetelmiään. Yhdessä oppiminen (vrt. L. Roberts tulkinnat, neuvottelevat keskustelut ) on ollut hankkeen kantava idea, joten koulut ja museot ovat tuottaneet hankkeen aikana paljon yhteisprojekteja. Koulutuksissa on ollut mukana enemmistönä perusopetuksen opettajat, mutta jossakin määrin myös toisen asteen opettajat ovat löy- 
täneet koulutukset. Tekniikan museo Helsingissä järjestää opettajien täydennyskoulutusta aktiivisesti myös elinkeinoelämää palvelevien järjestöjen kuten Taloudellisen tiedotuskeskuksen (TAT), Kemianteollisuus ry:n ja Teknologiateollisuus ry:n kanssa. Opetushallitus on museoiden aktiivinen yhteistyökumppani opettajien täydennyskoulutuksessa.

\section{Maahanmuuttajaryhmät}

Yhä lisääntyvä aikuiskasvatuksen muoto museoissa on aikuismaahanmuuttajaryhmien ohjelmat. Museoissa voidaan opetella uuden kotimaan mennyttä ja nykyistä kulttuuria sekä verrata omaa kulttuurista identiteettiä siihen kulttuuriin, jossa kulloinkin asuu. Maahanmuuttajaryhmille suunnitellut ohjelmat vaativat hyvää sisällöllistä suunnittelua. Ohjelmien pedagogisena suunnittelu- ja toteutusmenetelmänä käytetään hyväksi konstruktiivista oppijalähtöisyyttä. Robertsin mainitsemat keskustelut eri näkökulmista (omat kokemukset, muistot, assosiaatiot) ja niiden pohjalta tulkintojen tekeminen on museoympäristössä antoisa yhdistelmä.

Perinteinen behavioristinen, asiantuntijalta eiasiantuntijalle -opastus voi kielen hallinnan kannalta, puhumattakaan pedagogisesta näkökulmasta, olla vaikeakäyttöinen museoympäristössä. Tekniikan museolla toteutettiin museodraama vuonna 2007 metsäteollisuuden merkityksestä Suomelle historiallisesti sekä nykypäivänä näyttelyä hyväksikäyttäen. Yksi kävijäryhmistä oli maahanmuuttajaryhmä. Draaman hyväksikäyttö, tarinan kertominen asiasta, sai erittäin hyvää palautetta maahanmuuttajaryhmältä. Esitys herätti kävijöissä tunne-elämyksiä, muistoja ja ajatuksia suhtautumisesta metsään oman kulttuurinsa näkökulmasta. Näytelmän ja näyttelijöiden tunteiden ilmaisun avulla pystyttiin ilmaisemaan metsän ja sen antaman elannon merkitystä suomalaisille historian saatossa. Historian avulla päästiin tähän päivään, mitä metsäteollisuuden muutokset vaikuttavat koko yhteiskuntaan, jossa maahanmuuttajatkin elävät. Näyttelijöiden ilmeiden ja eleiden avulla ymmärrettiin vähäisellä kielitaidollakin, mistä oli kyse eri näyttelyinstallaatioiden ja esineiden äärellä.

\section{Uuden tekniikan hyväksikäyttö}

Puhuttaessa museosta oppimisympäristönä se ymmärretään usein toimintona, joka sijoittuu fyysisen museorakennuksen sisälle ja siellä etenkin näyttelyssä esillä olevien kokoelmien kohteisiin. Museota ei tule kuitenkaan tarkastella vain paikkana vaan näkökulmana, kuten Kalle Kallio kirjoittaa (Kallio, 2004). Nykyinen sähköinen teknologia on avannut museoille täysin uusia mahdollisuuksia. Esine-, valokuvakokoelmat ynnä muut arkistot ovat olleet usein vain tutkijoiden ja museon oman tutkimushenkilökunnan käytössä käytännön syystä. Vain suurimmissa museoissa on kokoelmien yhteydessä asiakaspalvelu- ja tutkimushuoneita tai -tiloja, jossa asiakkaat voivat tutustua kokoelmiin.

Museoilla on ollut 1990-luvulta lähtien opetusministeriön rahoittamia laajoja hankkeita kokoelmien saattamiseksi sähköiseen muotoon ja verkkoon. Uusin opetusministeriön hankkeista on Kansallinen digitaalinen kirjasto -hanke vuosille 2008-2011, jossa tavoitteena on edistää kirjastojen, arkistojen ja museoiden keskeisten kansallisten tietovarantojen saatavuutta ja käytettävyyttä tietoverkoissa. Aikuisoppijat voivat käyttää hyväkseen museoiden sähköisiä kokoelmalähteitä niin kuin muidenkin arkistojen lähteitä. Virtuaalinen maailma ja on-line-yhteys mahdollistavat Robertsin esittämän museoiden voimavaran aikuisten oppijoiden parissa: tarinat, elämänkokemukset ja nostalgia.

Museokokoelmien esineitä on arvotettu pitkään niiden myötäsyntyisellä museaalisella arvolla kuten harvinaisuus, alueellisuus ja aitous. Nykymuseologiassa korostetaan esineiden merkitystä niiden taustalla olevien tarinoiden, kontekstitietojen perusteella. Tarinattomat esineet, joita museoissa kuitenkin paljon vielä on, ovat Malmisalo-Lensun ja Mäkisen mukaan lähes arvottomia. Museon aikuiskävijoihin ja heidän immateriaaliseen pääomaansa on paneuduttu Tekniikan museolla kehitettävässä Innovaattori-tietokannassa. Museon kokoelmissa olevista esineistä, joiden kontekstitiedot ovat puutteellisia, pyritään saamaan lisätietoa ns. webbipohjaisen Innovaattori-kortin käytön avulla. Tekninen keksintö tai innovaatio, josta jollakin museon ulkopuolisella on kontekstitietoa, omakohtaista käyttöä, tarinaa, kuvamateriaalia tai uusia linkkejä. Niitä voidaan wikipedia-tyyppisesti liittää museon Innovaattori-tietokantaan. Tietokannan valmistuttua siitä voidaan tiedottaa erimerkiksi toisen asteen ja vapaa sivistystyön aikuiskoulutuksiin.

Elokuulla 2008 Tekniikan museossa toteutettiin 
matkapuhelinpohjainen pelikokeilu TekMyst, jota testattiin sekä nuorille kävijöille että suurelle yleisölle. Kokeilussa havainnoitiin matkapuhelimen ja pelin laajentamia mahdollisuuksia museonäyttelyympäristössä. Kokeilu toteutettiin Tekniikan museon InnoApaja-oppimisympäristöhankkeen ja Joensuun yliopiston tietojenkäsittelytieteen ja tilastotieteen laitoksen Ubique Lab -opetusteknologiatutkimusryhmän yhteistyönä. (Islas ym. 2008)

\section{Yritysasiakkaat - virkistäytymistä ja oppimista kulttuurilla}

Museoiden uusi ja tulevaisuuden tapa palvella aikuisyleisöjä on yritysten virkistyspäivien ohjelmat, jossa museot eivät toimi vain keventäjänä, vaan myös oppimispaikkana. Tekniikan museossa on kehitetty InnoApaja-hakkeen puitteissa näyttelyyn Ihmeelliset innovaatiot -peli, jota yritys voi varata pelattavaksi ohjaajan kanssa innovatiivisuuden ja luovuuden kehittämiseksi. Ensimmäiset kokeilut tehtiin kevään 2008 aikana. Palaute on ollut myönteistä innovatiivisen ja luovan ajattelun kehittäjänä samalla kun positiivinen asenne museosta aktiivisena oppimisen paikkana on kasvanut.

Marjatta Levanto (2004), yksi Suomen museopedagogiikan uranuurtajista 1970-luvulta lähtien, on ilmaissut museoiden suhteesta aikuiskävijöihin Teema04 -seminaarissa: "Kuitenkin me tiedämme, että yli 65-vuotiaat kaksinkertaistuvat määrältään kovaa vauhtia, että väestö ikääntyy. Myös lapsettomien avioparien määrä lisääntyy. Keskituloisten ja suurituloisten määrä nousee, mistä on luonnollisesti suora yhteys koulutukseen. Uuden vuosituhannen museovieras arvostaa oppimista, etsii haastetta uusista kokemuksista ja arvostaa merkityksellistä tekemistä vapaa-aikanaan. ... Ikään katsomatta ihmiset etsivät henkilökohtaisen kasvun mahdollisuuksia jatkuvan oppimisen kautta. Uuden vuosituhannen ihminen on utelias ja vaativa museovieras." Aikuiset voidaan edellä kirjoitetun perusteella sanoa museoiden jatkuviksi aikuisoppijoiksi, jotka on otettava huomioon museoiden toiminnassa entistä enemmän. Museoilla on aina ollut tehtävänä sivistää kävijöitään. Pedagoginen henkilökunta on lisääntynyt Suomen museoissa kiitettävästi 1990-luvulta lähtien. Näiden resurssien hyväksikäyttö aikuiskoulutuksessa on vielä suhteellisen vähäistä. Suunta tulevaisuudessa ei voi olla muuta kuin lisääntymään.

\section{Viitteet}

1. Termin englanninkielinen vastine on museum education (educate, kasvattaa, kouluttaa, opettaa, sivistää, kehittää, valistaa’ Sanakirja org, 2008)

2. Pedagogiikka-termi yhdistetään usein lapsiin ehkä sen alkuperän (kreikaksi paid, 'lapset', + agein, 'ohjata, johtaa') tai yleisen kielenkäytön mukaan (esim. lastentarhapedagogiikka, Steiner-pedagogiikka tai musiikkipedagogiikka). Termin käyttö on laajentunut viime vuosikymmeninä aikuiskohderyhmiin kuten yliopistopedagogiikka tai verkkopedagogiikka.

\section{Painettu kirjallisuus}

Airaksinen, Raija \& Eerola Meri (1997). Teatterikuraattori silta tekijän ja kokijan välillä. Teatterikorkeakoulun julkaisusarja no. 27. Helsinki.

Gesché-Koning, Nicole (2007). Museums and Education ICOM-CECA Publications 19522006. ICOM Education 20.

Hein, E. George (1998). Learning in the Museum. Routledge.

Heinonen, Jouko (2002). Museo 1/2002 . Museo oppimisympäristönä. Suomen museoliiton julkaisu. Helsinki: Suomen museoliitto. 31-32, 36.

Heinonen, Jouko \& Lahti, Markku (2001). Museologian perusteet. Suomen museoliitto. Suomen museoliiton julkaisuja 34.

Hirsjärvi, Sirkka \& Huttunen, Jouko (1997). Johdatus kasvatustieteeseen. 4.-5. painos. Helsinki: WSOY.

Hooper-Greenhill, Eilean, (Ed.) (1994). The Educational Role of the Museum. Leicester Readers in Museum Studies. Routledge.

Hooper-Greenhill, Eilean (Ed.) (1995). Museum, Media and Message. Routledge.

Houtgaard, Dirk \& Vitali, Vanda (2008). Mastering a Museum Plan. Strategies for Exhibit Development. Naturalis, The National Museum of Natural History. Leiden.

Islas Sedano, C., Laine, T.H., Vinni, M. and Sutinen, E. (2007). Where is the answer? - The importance of curiosity in pervasive mobile games. Proceedings of the Futures Play Con- 
ference. November 14-28, 2007. Toronto, Canada. ACM Press.

Kallio, Kalle (toim.) (2004). Museo oppimisympäristönä. Suomen museoliiton julkaisuja 54. Suomen museoliitto ja Suomen Tammi. Jyväskylä.

Kaitavuori Kaija (2007). Museo ja yleisö. Teoksessa Museologia tänään (toim. Kinanen P.).Suomen museoliiton julkaisuja 57. Jyväskylä.

Kaitavuori, Kaija \& Levanto, Marjatta \& Raivio, Nanne \& Venäläinen, Päivi \& Wahlbeck, Johanna (toim.). (2009). Pedafooni 2A: Opastamisen nykypäivää. Helsinki: Museopedagoginen yhdistys Pedaali ry.

Komiteamietintö - Kommittebetänkande 31 (1999). Museo 2000, museopoliittinen ohjelma. Opetusmininisteriö.

Malmisalo, A.-M. \& Mäkinen-Lensu, M. (2007). Museo oppimisen paikkana. Teoksessa $\mathrm{Mu}$ seologia tänään (toim. Kinanen P.).Suomen museoliiton julkaisuja 57. Jyväskylä.

Rauste-von Wright, Maijaliisa \& von Wright, Johan (1995). Oppiminen ja koulutus. Helsinki: WSOY.

Roberts, Lisa C. 1997. From Knowledge to Narrative. Educators and the Changing Museum. Washington. Smithsonia Institution Press.

Salmi, Hannu (1993). Science Centre Education. Motivation and Learning in Informal Education. Research report 119. Department of Education. University of Helsinki.

\section{Internet}

Levanto, Marjatta 2004. Johdatuspuheenvuoro seminaarissa Teemapäivät 4.-6.2.2004 Elinikäinen oppiminen ja tiedollinen saavutettavuus - aikuiskävijä museon vieraana. http:// www.fng.fi/fng/rootnew/fi/kehys/teema04/materiaalit/johdanto.pdf [21.8.2008]

Opetusministeriön tiedotteet, http:// www.minedu.fi/OPM/Tiedotteet/2008/06/ digikirjasto.html [21.8.2008]

Sanakirja.org http://www.sanakirja.org/ search.php?q=educate\&l=3\&l2=17 [20.8.2008]

Suomen ICOM komitea, suomennos http:// finland.icom.museum/etiikka.html) [20.8.2008]
Suomen museopedagoginen yhdistys Pedaali ry. www.pedaali.fi [12.6.2008]

\section{Suulliset lähteet}

Sjöberg, Karin (2008). Luento Arkiven - en pedagogisk resurs. Seminaarissa Att spränga gränser, tidsresor och arkivpedagogik - Rajojen rikkominen, aikamatkoja ja arkistopedagogiikkaa. Suomen kansallismuseo 25.8.2008. Järjestäjinä Helsingfors stad kulturcentral/ Helsingin kaupungin kulttuuriasiainkeskus, DOT r.f., Finlands nationalmuseum/ Suomen kansallismuseo, Svenska Litteratursällskapet, Finlands museiförbund/Suomen museoliitto 